\title{
Professor Chakkiri Balakrishnan: The Guru of Gurus
}

"Mahajano Yen gata sa pantha"

("Follow the path tread by great wise people")

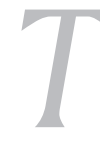

he Mahabharata (Vana -parva 313.117)

'Dr. Balakrishnan was a scholarly and modest man. He was original with genuine flair for Plastic Surgery. Men of his caliber are rare and should be fostered and given opportunities to match their natural talents and drive.'

Sir Benjamin Keith Rank in the book 'Head and Hands: An Era of Plastic Surgery' published by Harper and Row, Sydney (1987).

Dr. C. Balakrishnan (popularly known as CBK) [Figure 1] was a remarkable person, a colossus and can be truly called the Father of Plastic Surgery in modern India. He envisioned the need of creating the speciality of plastic surgery in India and relentlessly worked towards achieving this mission. He laid solid foundations on which the current edifice of the Indian Plastic Surgery has been erected. The life story of CBK is all about the trials and tribulations of an extraordinary man who established the very roots of the speciality of Plastic Surgery in India.

He was born on April 1918 in Ambathodi House, Marakkara in Southy Malabar of the old Madras Presidency and was the youngest of the three siblings. Being underage for the medical school, he first completed his BSc in Physics from Madras Presidency College. He finished his

\begin{tabular}{|l|l|}
\hline \multicolumn{2}{|c|}{ Access this article online } \\
\hline Quick Response Code: & Website: \\
\hline & www.ijps.org \\
\hline & \\
\hline
\end{tabular}

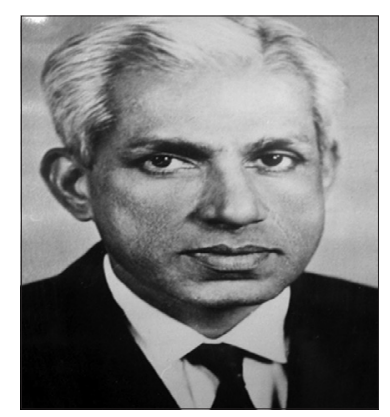

Prof. Chakkiri Balakrishnan

undergraduate medical studies from the Madras Medical College in 1941 and won almost all the academic medals in the college. He was also a diploma holder in the German language. Soon after completing his MBBS, he joined the Indian Army Medical Corps on an emergency war commission as a parachutist. [Figure 1] After the war, he had trained for 2 years in plastic surgery with the army. Subsequently, he was sent to the UK. for higher studies on a scholarship by the Government of India. He worked in Plastic Surgery units at London, Nuffield, Stoke Mandeville, Manchester and other places from 1947 to 1949. During this period, he became a Fellow of the Royal College of Surgeons (London). While he was in the UK, he was in constant touch with the Government of India through the Director General of Health Services proposing to start a department of Plastic and Maxillofacial Surgery. He strongly felt the need for one such facility in India. On his return to India in 1950, he was offered the post of lecturer in surgery at the Nagpur Medical College. In the next 2 years, he had performed 233 plastic surgery operations and impressed everyone with his surgical skills, missionary zeal and commitment. He continued relentlessly in his efforts towards creating an awareness towards creation of an independent plastic surgery department. His efforts got a shot in the arm when Dr. B K Frank from Australia came on a goodwill visit to Nagpur under the Colombo Plan. He was very impressed with the work and enthusiasm of Dr. CBK. Thanks to the clout and strong recommendations of Dr. Frank, a Plastic and Maxillofacial Surgery unit was eventually created in Medical college, Nagpur, with Dr. CBK as its professor

This is an open access journal, and articles are distributed under the terms of the Creative Commons Attribution-NonCommercial-ShareAlike 4.0 License, which allows others to remix, tweak, and build upon the work non-commercially, as long as appropriate credit is given and the new creations are licensed under the identical terms.

For reprints contact: reprints@medknow.com

How to cite this article: Sharma RK. Professor Chakkiri Balakrishnan: The Guru of Gurus. Indian J Plast Surg 2018;51:3-6. 


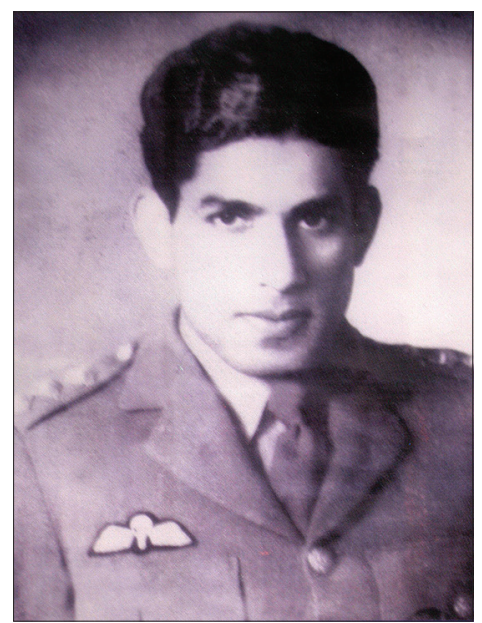

Figure 1: Young Captain Balakrishnan in the Indian Army

and head on $16^{\text {th }}$ December 1957. Later, more posts were created including the lecturer and reader in plastic surgery, a dental surgeon, a physiotherapist and an occupational therapist. The first M.Ch. course in plastic surgery was started in 1960 . He was joined by Dr.J L Gupta as a reader who had just come back from the UK. The department became very famous and soon many young surgeons started flocking to Nagpur for training in Plastic surgery. Dr. CBK had great ambition to establish an All India Institute of Plastic Surgery at Nagpur but was often frustrated with the bureaucratic apathy at Nagpur. Around this time, a new medical institute was coming up at Chandigarh in Panjab in North India. The dynamic chief minister of Panjab, Partap Singh Kairon convinced Dr. CBK to join the then-fledgling Plastic Surgery Department at PGIMER, Chandigarh, as the professor and head in 1966. Dr. Balakrishnan established a department which was soon to become the benchmark for plastic surgery training in India. He continued to take his department at PGIMER to greater heights with the help of an excellent faculty, including Dr. C P Sawhney and trained a large number of students from all the corners of India. He trained 13 plastic surgeons in Nagpur Medical College and 31 students in PGIMER, Chandigarh. Many of his students have gone on to illustrious careers in plastic surgery; notables among them include Dr. C S Sundararajan, Dr. Sam C Bose, Dr. R Venkataswamy, Dr. L K Sharma, Dr. S N Sharma, Dr. P S Chari, Dr. R K Nair, Dr. Ashok Govila and Dr. P A Vinod Kumar.

He introduced the concept of treatment planning sessions in which the resident would present a case in front of the house that included the residents and the faculty. It was an exercise in identifying and analysing the problems, defining the aims of treatment and discussing the modalities of executing the plan. The planning sessions could be ordeals for the residents and faculty, but CBK's vision and critical analysis were long remembered by all the participants. His ward rounds were a lesson in bedside manners, empathy and discipline. He asked very probing questions and applauded the correct answers. The knowledge of the participants was teased and tested.

He was very particular about the cleanliness and aseptic techniques. He also introduced the concept of dressing rooms for the plastic surgery patients. He would ensure that aseptic techniques were followed just like in an operation theatre. His operation notes were precise with clear diagrams. The case notes of the patients he assisted at or operated on during his training days during the war services are models of accurate documentation with good photographs. His operations were methodical with intense concentration and each phase of the procedure proceeded like an effortless symphony of mind, eye and hand. Dr. Sam Bose described it as 'poetry in action.' He could use both his right and left hands with ease and the execution of his surgical steps was a sheer joy to witness. He liked pin-drop silence during the operative procedure and hated any disturbance while operating and would not tolerate any chatter during the surgery.

He led by example and he would never compromise on doing best for the patient. The Director PGIMER, Dr. Santokh Singh Anand narrated the following incidence in the first annual report of PGIMER on the table of Lok Sabha in 1967:

"A specialist surgeon (CBK) on his night rounds in the wards dropped into see what happened in the Emergency Department at $9.30 \mathrm{pm}$. He saw a woman just brought in for loss of her right thumb. She was holding a buffalo calf by the tie-rope. The calf bolted, the rope tightened round her thumb and pulled it off. Asked where the missing part was, she said that it had been left at home because people thought it futile to take it with her to the hospital. Her home was in village 15 miles away, but the road was good. The surgeon (CBK) opted for the best he could do to reconstruct her thumb using what could be salvaged from the avulsed part. Speed was vital if the tissues were to survive. There was no faster transport than his own car. So, he drove to the village with the woman's husband. The thumb was retrieved and brought back in an ice-container. It was fast work and took $50 \mathrm{~min}$. 
Meanwhile the theatre team had prepared the woman for the operation and everything required was ready when the surgeon got back with the thumb. The skin of the avulsed thumb with no surviving potential was dissected off. The viable assembly of bones, joints and tendons valuable for future function was reattached. It was then fixed under a flap of skin on the abdomen to provide skin cover and new blood supply. The emergency operation was the first step in a sequence of four subsequent operations to provide a useful right thumb. The lesson went home to young doctors under training".

His sense of dedication to the nation was infectious. Despite shortcomings and national crisis, he always took an optimistic view of where India was headed, and in the ultimate success of India as a nation. In his-Gillies Memorial Oration delivered at Calcutta in 1973, he said 'the lure of Plastic Surgery in India was that the work was fantastic in its variety and supremely satisfying to do. Working hard to meet the challenge of difficult cases and feeling this effort bringing forth our best talents and giving us great job satisfaction is the major part of our laurels....We are privileged to give a great part of our time every day to make some derelict human being more able to get back into the mainstream of useful independent life....'

He had started the concept of multidisciplinary approach in the management of cleft lip and palate, head and neck cancer and hand deformities/injuries. The combined clinics with orthodontist, radiotherapist, occupational therapist, dental surgeons and speech therapist were started during his time and continue to function as efficiently even today.

Dr. Balakrishnan was a multitalented person. He was not only a pioneering expert in the field of plastic surgery but was also an expert machinist with his own workshop at home, an ace photographer, a ham radio operator, a keen gardening expert and an exploring traveller who covered every corner of India as well as many countries abroad. He was a long-standing member of the Rotary Club. In 1957, the Plastic Surgery section of the Association of Surgeons of India was formed during Harold Gillies visit and Dr. Balakrishnan remained President from 1958 to 1960 . Gillies continued his close relations with the Nagpur unit of Dr. CBK [Figure 2].

In 1978, he received the Dr. B. C. Roy Award in recognition of merit as an Eminent Medical Teacher in Plastic Surgery. He was Fellow of the National
Academy of Medical Sciences. He was also a Life member of the Indian Association of the Advancement of Medical Education, Convener of specialty group for Plastic Surgery of the National Board of Examinations and Founder Secretary (and later President) of the Nagpur Association for Rehabilitation of Children with Orthopedic Deformities (1956-1966). The Medical Council of India accepted his recommended 'Training in Plastic Surgery' as the basis for courses leading to the M.Ch. (Plastic Surgery) in 12 centres in India.

Dr. Balakrishnan innovated several operative techniques though he did not publish them. He was kind of averse to the idea of publishing in the journals. It has been such a big loss to the future generations of budding plastic surgeons. I could collect the following innovations of CBK:

1. Triple wedge technique for cleft lip repair

2. Two types of vomer flaps complete unilateral and bilateral clefts of the lip and palate

3. Classification of cleft lip and palate, now known as Nagpur classification

4. Toe to thumb transfer by skin flaps and sutured hand to foot by a system of pulleys and weights on a Balkan frame

5. Toe joint transfer for adults with temporo mandibular joint ankylosis

6. A pull though-shoe lace knot with loop on the mucosa, vertical oblique mattress suture for reconstruction of the anterior urethra in hypospadias

7. Cheek skin-buccinator mucosa flap carried on upper lip for reconstruction of major loss of upper eyelid after excision for carcinoma

8. Acromio-scapular sandwich flap for reconstruction of major defects after excision of oral cancers

9. Pharyngoplasty using fascia lata sling.

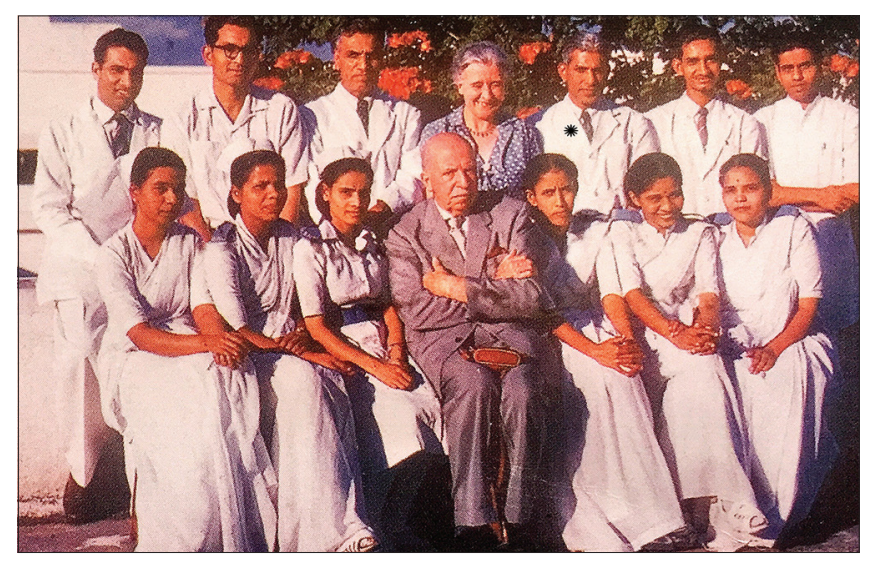

Figure 2: A group photograph with Harold Gillies in Nagpur in 1959 
The senior faculty members of PGIMER surgical fraternity remember Prof. CBK very reverently and all of them say that he was very honest, hardworking and commanded respect from one and all. His patients literally worshipped him. We do keep seeing his operated patients of cleft lip and palate and all these patients bear the stamp of his craftsmanship. The speech of most of these patients is excellent. Some of the patients of cheek defect and cancrum oris treated with conventional arm/back tubes are a lesson in perfect execution of well thought out plan.

His teachers had high praise for CBK. Professor Kilner wrote. 'He had distinguished himself in our discussion sessions by his often lucid and ingenious presentation of cases or of subjects handed to him for study and critical review. As an assistant and operator, his surgical craftsmanship is outstandingly good.' Mr. AHR Champion of Manchester wrote: 'I have formed a very high opinion of Dr. Balakrishnan's ability as a Plastic Surgeon. He is extremely patient and meticulous of detail which is so important in work of this nature.'

He retired in April 1980 and continued giving care to the needy in private practice at a very nominal fee. We had an occasion to see him during the APSICON 1985 at Chandigarh. All the people jostled around him in a rare group photograph [Figure 3]. He, unfortunately, developed Parkinsonism that gradually eroded his surgical skills and he stopped operating in the mid-90s. He succumbed to this crippling disease in 1997.

The Plastic Surgery fraternity in India will always be grateful to the vision of CBK for establishing the roots of Modern Plastic Surgery in the country.

The famous couplet from Allama Iqbal befittingly sums up the persona of Dr. Balakrishnan.

Hazaron Saal Nargis Apni Benoori Pe Roti Hai

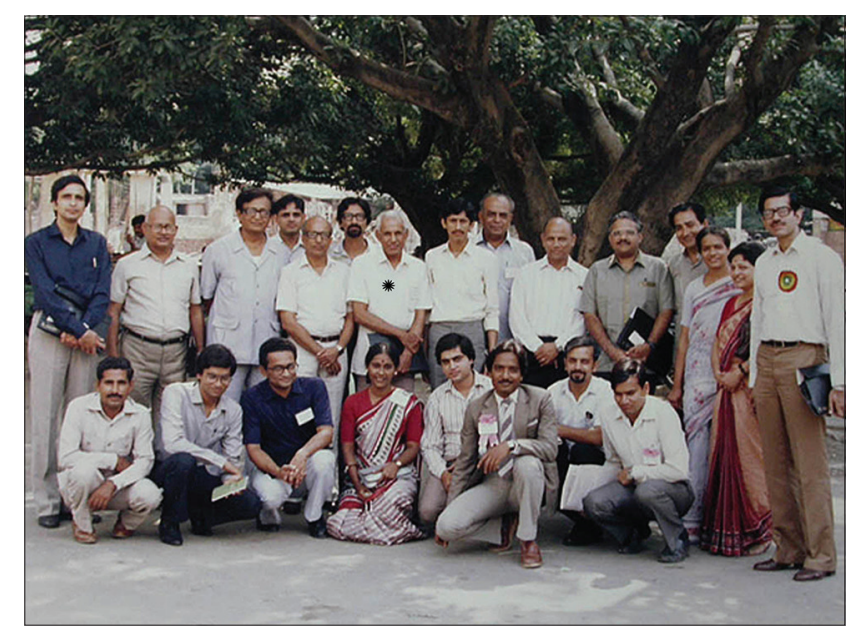

Figure 3: Group photograph during the APSICON 1985 at Chandigarh

Bari Mushkil Se Hota Hai Chaman Mein Didahwar Paida

(For 1000 years, the narcissus has been lamenting its blindness; with great difficulty, the one with true vision is born in the garden.)

His legacy will continue to guide us forever. We are indeed blessed to have someone like him guide the destiny of the speciality in India.

\section{Financial support and sponsorship}

Nil.

\section{Conflicts of interest}

There are no conflicts of interest.

Ramesh K. Sharma

Department of Plastic Surgery, PGIMER, Chandigarh, India

Address for correspondence: Dr. Ramesh K. Sharma, Department of Plastic Surgery, PGIMER, Chandigarh - 160 012, India. E-mail: drsharmark@gmail.com 